\title{
ASEAN Intervention in Cambodia: From Cold War to Conditionality
}

\author{
Lee Jones
}

\begin{abstract}
Despite their other theoretical differences, virtually all scholars of the Association of Southeast Asian Nations (ASEAN) agree that the organisation's members share an almost religious commitment to the norm of non-intervention. This article disrupts this consensus, arguing that ASEAN repeatedly intervened in Cambodia's internal political conflicts from 1979-1999, often with powerful and destructive effects. ASEAN's role in maintaining Khmer Rouge occupancy of Cambodia's UN seat, constructing a new coalition government-in-exile, manipulating Khmer refugee camps and informing the content of the Cambodian peace process will be explored, before turning to the 'creeping conditionality' for ASEAN membership imposed after the 1997 'coup' in Phnom Penh. The article argues for an analysis recognising the political nature of intervention, and seeks to explain both the creation of nonintervention norms, and specific violations of them, as attempts by ASEAN elites to maintain their own illiberal, capitalist regimes against domestic and international political threats.
\end{abstract}

\section{Keywords}

ASEAN, Cambodia, Intervention, Norms, Non-Interference, Sovereignty

\section{Contact Information}

Lee Jones is a doctoral candidate in International Relations at Nuffield College, Oxford, OX1 1NF, UK. His research focuses on ASEAN and intervention in Cambodia, East Timor, and Burma. Comments are welcomed. Email: lee.jones@politics.ox.ac.uk. Tel/Fax: (+44) (0)1865 28890. 


\section{ASEAN Intervention in Cambodia: From Cold War to Conditionality}

\section{Introduction}

Discussion of ASEAN's normative regimes like the Treaty of Amity and Cooperation (TAC) and the Zone of Peace and Neutrality (ZOPFAN), resistance to human rights criticism, or the development of the ASEAN Regional Forum (Acharya, 2001; Tang, 1995; Leifer, 1996) have all emphasised the cardinal norms of 'rigidly demarcated and sacrosanct boundaries, mutual recognition of sovereign political entities, and nonintervention in the affairs of other states', apparently proving Mohammed Ayoob's (1995: 71) observation that 'third-world elites have internalised these values to an astonishing degree'. To such a degree, indeed, that this paralysed ASEAN during and since the 1997-98 Asian financial crisis. Analysts referred to ASEAN's 'nonintervention problem', declaring that 'either interference becomes legitimate, or the Association will become increasingly meaningless. The ASEAN Way ends here'(Moller, 1998: 1104). ${ }^{1}$ This article challenges this consensus by showing that ASEAN states repeatedly intervened in the internal political conflicts of Cambodia between 1979, when Vietnam invaded Cambodia and overthrew the Khmer Rouge, and 1999, when Cambodia was finally admitted to ASEAN.

The Cambodian case is complex, raising many issues and resisting easy summarisation. It is chosen here because of its well-recognised centrality to the unity and development of ASEAN in the 1980s. Its selection also highlights the indeterminacy of the literature on ASEAN norms. During this period Cambodia was not an ASEAN member, and so it might simply be argued that ASEAN's 'norms' did not apply or were not violated by intervention. However, the virtually uncontested interpretation of ASEAN's stance on Cambodia was that it was motivated by 'embarrassment' at the violation of its 'cherished' norm of non-intervention by Vietnam, and did not intervene itself (e.g., Acharya, 2000: 79-129; Alagappa, 1993; Antolik, 1990: 116; Leifer, 1999: 35). This strongly implies that despite the absence of Vietnam and Cambodia from its ranks, ASEAN acted as if the norm extended to Indochina. However, this article will demonstrate that despite its rhetorical adherence to non-interference, ASEAN repeatedly violated its own norms in response to Vietnam's behaviour. This challenges the claim that ASEAN states' identities and interests had been 'transformed' by norms via a process of 'socialisation', as the 'security community' literature argues (Acharya, 2001), and falsifies Leifer's (1999: 35-6) assertion that ASEAN's approach to Cambodia from 1997-99 was only the second time it had ever intervened in the internal affairs of another country. ${ }^{2}$

Beginning with a political, historicised reading of ASEAN's non-intervention norms, the article traces ASEAN's intervention (understood as coercive interference in an external political community) through the second Cold War and into the 1990s, drawing a contrast between the strong intervention of the 1980s, driven by the imperative to contain revolution, and the weaker intervention of the 1990s, driven mainly by a need to maintain a suspect claim to manage regional order. ${ }^{3}$

\section{ASEAN's Non-Interference Norms: A Politicised Reading}


As Lee Kuan Yew (2000: 369-70) states, ASEAN's prime raison d'être was to facilitate the continued survival of authoritarian capitalist regimes threatened by internal subversion and the external pressure of the Cold War:

[t]he unspoken objective was to gain strength through solidarity ahead of the power vacuum that would come with an impending British and later a possible US withdrawal... We had a common enemy - the communist threat in guerrilla insurgencies, backed by North Vietnam, China and the Soviet Union. We needed stability and growth to counter and deny the communists the social and economic conditions for revolutions... While ASEAN's declared objectives were economic, social and cultural, all knew that progress in economic cooperation would be slow. We were banding together more for political objectives, stability and security.

ASEAN was made possible, as Indonesian Foreign Minister Adam Malik pointed out, by the 'convergence in the political outlook of the five prospective member-nations' (Khong, 1997: 327) after Sukarno's crusading anti-imperialism was brought to a bloody end by Suharto's New Order regime. The alignment of reactionary capitalist regimes across the sub-region allowed leaders to cooperate in defeating the key threats to their rule: internal subversion, particularly the threat of communist revolution, against which most ASEAN states had concluded bilateral arrangements by the late 1970s (Snitwongse, 1995: 521).

ASEAN's key 'norms' of non-interference, enshrined in the 1967 ASEAN Declaration, the 1971 ZOPFAN Declaration and the 1976 TAC, merely reiterate, in a strict tone, rules already articulated in the UN Charter. That these rules already existed elsewhere begs the question as to why ASEAN would want to recapitulate them. The answer lies in the timing and political functions of each declaration. The ASEAN Declaration aimed to halt the rampant intervention against each other's rule that had characterised regional international relations hitherto, 'to ensure [members'] stability and security from external interference in any form... in order to preserve their national identities' (ASEAN, 1967). The goal was to give authoritarian elites sufficient latitude to engage in violent political consolidation in an era when 'national identities' were weak or non-existent. ZOPFAN and TAC were direct responses to the deteriorating international environment and the rising power of communist insurgencies. By the mid-1970s, for example, Thailand and the Philippines had both succumbed to dictatorships in reaction to deepening economic malaise and the growing leftist threat to entrenched economic and political power structures. Marxist guerrillas were active throughout those countries, effectively ruling over hundreds of thousands of people (Alexander, 1999: 314; Anderson, 1998: 171-83; Kessler, 1989; Girling, 1981: 257).

To deny the opening for great power intervention provided by civil strife in Indochina, ASEAN vowed to strengthen 'national resilience' to ensure 'stability and security from external interference... in order to preserve... national identities' (ASEAN, 1971). But with the onset of the Nixon Doctrine, ASEAN had to go further and 'reserve', as Marcos put it, 'the right to make our own accommodations with the emerging realities in Asia' (Silverman, 1975: 920-1). TAC, emerging in the context of the enormous boost given to the region's communist movements by revolutionary victory in Indochina in 1975, stressed 'mutual respect for the independence, sovereignty, equality, territorial integrity and national identity of all nations', 'the right of every State to lead its national existence free from external interference, subversion, or coercion' and 'non-interference in the affairs of one another' (ASEAN, 
1976). ASEAN hoped to contain the spread of revolution by offering this quid pro quo to Indochina's new communist states, in the vain hope they would adopt a selfdenying ordinance.

ASEAN's international 'norm' of non-intervention was actually a domesticallydetermined political principle, developed to defend weak, capitalist regimes from externally sponsored revolution. As Justin Rosenberg argues, "the "international" has also been very much about the management of change in domestic political orders... a counter-revolutionary foreign policy is rarely just a foreign policy. To a degree which varies with individual cases it is also directed inwards, a nationalist identification of certain programmes of domestic political change with a foreign threat' (Rosenberg, 1994: 35). Since interventions are essentially actions designed to change political outcomes in an external political community, we could regard as interventionist such actions as Malaysia's military aid against communist guerrillas in Indonesian Borneo, successful Malaysian-Indonesian efforts to defuse the Muslim insurgency in the southern Philippines, and ASEAN's backing of Indonesia's annexation of East Timor. That such actions were welcomed indicates that what ASEAN elites sought to defend was not an abstract normative principle but their own precarious social orders - all of which were shored up in these instances. The same pattern is expressed in Thailand's sponsorship of armed rebel groups in Burma on the understanding that they would help crush the Communist Party of Thailand and prevent it linking up with the Communist Party of Burma (Smith, 1991: 297-99). When Vietnam invaded Cambodia in December 1978, overthrowing Pol Pot and installing a new government, the People's Republic of Kampuchea (PRK), and forcing Khmer Rouge (KR) remnants to flee to the Thai border, it raised the spectre of spreading revolution and toppling 'dominoes'. ${ }^{4}$ Despite their rhetorical adherence to the 'norm' of non-intervention, ASEAN was driven by this spectre to intervene in the Cambodian conflict.

\section{Intervention in the 1980s: Representation, Rebels and Refugees}

\section{Representation: ASEAN's UN Activism on behalf of the Khmer Rouge}

The UN Security Council considered Vietnam's intervention in January and February 1979, but was paralysed by Sino-Soviet rivalry. The USSR vetoed proposed resolutions against its Vietnamese ally, while Beijing invaded northern Vietnam to 'punish' Hanoi for overthrowing its client regime in Cambodia. Attention thus shifted to the UN General Assembly (UNGA).

The question of who gets to represent a state at the UN is normally a purely bureaucratic process overseen by the Credentials Committee, whose annual reports are usually rubber-stamped without debate by the UNGA. ASEAN politicised this process by successfully campaigning each year for the KR to keep Cambodia's UN seat. This was a move without precedent and carried serious consequences for the balance of forces inside Cambodia. Using the rhetoric of a defence of nonintervention, ASEAN mobilised third-world states in the UNGA to vote against the PRK's credentials in favour of those of Democratic Kampuchea (DK), represented by Ieng Sary, Pol Pot's deputy; sponsored critical annual resolutions on the 'Situation in Kampuchea'; and hijacked Vietnam's counter-debates on 'Peace and Stability in Southeast Asia' to lambaste Hanoi. 
ASEAN argued that the PRK was a 'puppet regime' established by armed intervention, and that seating it would endorse violations of basic norms of international conduct (A/34/PV.4: 37-8; A/34/PV.4: 51; A/34/PV.62: 1195, 1210; A/34/PV.65: 1251; A/35/PV.34: 687, etc). ${ }^{5}$ Ambassador Romulo of the Philippines argued, for instance, that seating the PRK would 'set in train a fatal sequence of events... the small and weak nations of the world' would lose 'the right to exist except under conditions of bondage and servility' (A/35/PV.35: 716). The rhetorical linkage of the Cambodian conflict to the UN Charter principles and the majority interests of weak states allowed Singaporean Ambassador Koh to claim that 'our opposition to Vietnam's action is based upon principle' and 'the right of DK to retain its seat in the UN has become coterminous with the defence of certain fundamental principles of the Charter of the UN' (A/34/PV.62: 1209; A/35/PV.34: 689).

It would be easy to take such rhetoric as a sign of commitment to the non-intervention norm, as many constructivists do. Comparing ASEAN's campaign to its reaction to other interventions, however, reveals its stance as political, not principled. The closest parallel is the January 1979 Tanzanian intervention in Uganda which overthrew Idi Amin. The circumstances prompting the intervention were similar; Tanzania advanced a 'two wars' thesis identical Vietnam's, claiming it acted in self-defence while a simultaneous indigenous uprising actually overthrew the government; and Tanzanian troops remained in Uganda for several years, policing the post-war political settlement. Yet by 1980, the new regime was seated at the UN, was recognised by over 80 governments, and ASEAN had raised no hue and cry (Amer, 1992: 207-9; Tesón, 1997: 116; Wheeler, 2000: 119-20; A/34/500/Add.1; A/34/500/Add.1: 3). The Soviet invasion of Afghanistan in the same year likewise produced little reaction from ASEAN members. Only two spoke at the UN debate and ASEAN rejected Thailand's suggested joint statement and 'restructuring' of SEATO. Thai Foreign Minister Siddhi admitted this was because the intervention had 'no direct bearing' on the region (S/13724/Add.1; S/PV.2185: 5; Van der Kroef, 1980: 488-9). The new regime was seated at the UN with only a handful of hollow reservations, with Singapore, a member of the Credentials Committee, voting in favour - hardly a robust defence of 'principle' (A/35/484: 2-4). Nor had ASEAN campaigned against France's 1978 intervention to overthrow the Central African Empire's government; the new regime was seated without a formal vote (A/35/PV.35: 704-5, 709-10; A/36/PV.103: 1871-2).

ASEAN's campaign was thus deeply politicised. Its interventions were crucial. It was exceptional for an overthrown government to retain its UN seat, and it carried serious consequences for the course of the Cambodian conflict. ASEAN was thereby able to deny Vietnam and the PRK victory, and to use the UN and its organs to propagate its view of the conflict. ASEAN's campaign of isolation also deprived the PRK of the usual aid and development assistance usually afforded to poor countries (e.g. from UNICEF, World Food Programme (WFP), the IMF, World Bank, etc), which made it harder for the new government to achieve 'performance legitimacy'(Alagappa, 1995), despite its domestic supremacy. Finally, the UN seat was ASEAN's bargaining chip, without which, as Ambassador Koh put it, there would be 'no incentive [for Vietnam] to negotiate a political settlement' favourable to ASEAN's interests (A/35/PV.34: 689). 
Just as DK's survival at the UN was impossible without ASEAN backing, so the KR's military survival was impossible without Thai assistance. Ieng Sary was saved from Vietnamese capture by being airlifted to safety by Thai forces. By January 1979 the Thais had prepared camps for KR soldiers on Thai soil, where they were fed, given medical treatment, and sent back over the border to fight the Vietnamese. While the border was mined to keep fleeing refugees out, Thai army trucks took KR soldiers across at safe points away from Vietnamese forces. Thai generals confirmed that this direct violation of the international law on neutrality was official policy. KR bases were established on Thai soil and the island of Khemara Phumin was fortified as an entrepôt for Chinese arms. By 1980, Thailand was accused of shipping 500 tons of arms to the KR every month. US intelligence estimated Thailand's army funnelled $\$ 100 \mathrm{~m}$ of arms annually to the KR during the 1980 s. Thai artillery was often used to cover KR forays into Cambodia and Thai soldiers would frequently interpose themselves to prevent 'hot pursuit' by Vietnamese forces (BP, 1979; Daily Telegraph, 1979a, 1979b; Guardian, 1979; Kiernan, 2002: 488; Shui, 2002; ST, 1979b, 1979c, 1979a; Van der Kroef, 1990: 235).

Without Thailand's assistance, the KR could not have survived as a threat to the PRK. Chinese and Thai aid allowed the KR to rebuild its forces from under 2,000 to around 40,000. This brought enormous dividends to Thailand's military regime. Most importantly, Beijing dropped its support for the Communist Party of Thailand (CPT), urging it to sign a truce, suspending the provision of broadcasting facilities in Yunnan province, and declaring by 1981 that it would not allow the CPT to sour Sino-Thai relations (Alexander, 1999: 316). Chinese aid to the Bangkok regime totalled $\$ 283 \mathrm{~m}$ from 1985-89 alone, and the military also gained preferential access to advanced weapons technology and oil (Kiernan, 1993: 218; Shawcross, 1984: 126). This, and the rhetoric surrounding the communist threat allowed the military to control a fifth of the national budget by 1982, shoring up the capitalist dictatorship (Paribatra, 1984: 40-41). Assisting the KR also created a buffer zone to contain the possible spread of revolution, and ensured that authority within Cambodia remained contested, which legitimised ASEAN's continued activism on behalf of DK. As DK's representative at the UN recognised, 'if the fundamental struggle were to be eliminated, there would be no reason for our debates here, because the Hanoi expansionists would already have achieved in the field the fait accompli of their invasion of Kampuchea' (A/36/PV.36: 722).

ASEAN's treatment of refugees fleeing Cambodia was also designed to harm the PRK. Initially, ASEAN states sought to keep the refugees out, believing them to be 'fifth columnists' sent to foment revolution. A senior Thai officer estimated that 'at least 10 per cent' were 'Hanoi spies' sent to 'undermine the government', and Bangkok forcibly repatriated tens of thousands into minefields, killing many. Singapore called refugees 'human bombs', refusing to accept any, while Malaysia threatened to deport 65,000 of them and adopt a 'shoot-on-sight' policy (Antolik, 1990: 117; Mysliwec, 1988: 95-6; Observer, 1979; Richardson, 1982: 102-7). However, this anti-communist hysteria gave way to a more manipulative policy when 'the strategic value of the refugees as a buffer along the border and as a source of support for the re-emerging resistance movement' was recognised (Terry, 2002: 119). Thailand declined to classify those crossing the border as refugees, thereby denying 
them international legal protection and ensuring that the lead agencies on the border would be the WFP and UNICEF, not the UNHCR with its powerful protection mandate (Amer, 1996: 121). This allowed the refugees to be manipulated in three crucial ways.

First, they were used as a population base for the KR and the other resistance factions, which included the Khmer People's National Liberation Front (KPNLF, led by Son Sann, a former Cambodian Prime Minister who declared his own liberation government) and Moulinaka (a royalist group led ostensibly by Prince Sihanouk, the former head of state). With the assistance of Thai Task Force 80, civilians were kept captive in these groups' camps, to which tens of thousands of refugees were forcibly transferred from temporary UNHCR facilities. The UN Border Relief Organisation (UNBRO), set up by the WFP upon its withdrawal in 1983, reported that by 1987 the guerrillas controlled all of the refugee camps and over 260,000 civilians. ASEAN campaigned annually for UN aid, 50 to 90 per cent of which was directly appropriated for the war effort. A 'top UN official' admitted in 1987 that 'the border operation is a political operation. It's the UN system being used to keep the game going'. Another remarked, 'if the UN stopped feeding the soldiers' wives and families, the resistance would stop' (Terry, 2002: 73, 115, 130-1, 137-9; Vickery, 1987: 318-20; NYT, 1979a; Mysliwec, 1988: 99). Second, the refugees were used to 'shame' Vietnam and provide 'proof' of the PRK's unpopularity (though most refugees were fleeing Thaifacilitated warfare). Michael Vickery argued that the UNHCR camp at Khao-I-Dang was deliberately established to attract refugees across the border to assist in these efforts, only to be closed in 1987 when civilians began fleeing the resistance camps en masse (Vickery, 1987: 309-10). Third, the refugees formed a useful, flexible 'human buffer'. Whenever the Vietnamese launched offensives against the resistance camps, such as their 1979 and 1983 raids on KPNLF headquarters at Nong Chang (located on Cambodian soil), ASEAN issued shrill denunciations, claiming Vietnam was 'invading' Thailand and 'slaughtering' Cambodian innocents in refugee camps: the resultant outcry induced Vietnam to withdraw. However, Thailand had actually provoked both attacks by seeking to smuggle thousands of guerrillas into Cambodia under the guise of 'refugee repatriation' (Van der Kroef, 1981: 519; 1983: 19; Vickery, 1987: 317; A/35/PV.35: 705). This buffer of human misery also proved most lucrative for the Thai army and the KR, which controlled the local black-market trade. Cross-border trade was estimated at $\$ 500,000$ per day by 1983 , and by 1989 , the KR were earning $\$ 2.4 \mathrm{~m}$ per month from territory they controlled with Thai assistance (Van der Kroef, 1983: 26; Um, 1989: 101).

\section{Representation: ASEAN and the Formation of the CGDK}

The military imperative of merging the Khmer resistance groups into a 'united front', and the diplomatic imperative of distancing ASEAN from a genocidal regime prompted ASEAN to begin leading the attempt, as Lee Kuan Yew put it, 'to preserve the DK seat in the UN and alter the leadership of the Government of DK'

(Saravanamuttu, 1996; ST, 1980a, 1980b), since Sihanouk and others had refused the genocidaires' request to unite (NYT, 1979b; ST, 1979d; IHT, 1979; Yomiuri Shinbun, 1979). The urgency of this task increased when the EEC hinted it might vote against DK at the UN in 1982. ASEAN feared that others might follow suit, leading eventually to the recognition of the by-now-enraged PRK (Tasker, 1982). ASEAN thus redoubled its efforts, using a raft of incentives and threats. 
After nine unsuccessful meetings in Bangkok, Son Sann was invited for secret talks in Singapore in April 1981 (Tasker, 1982; ST, 1981c). By May, Singapore's Foreign Minister explained that the aim was no longer a 'united front' but a 'coalition government' as 'the term... carries with it more authority, legitimacy and permanence' (ST, 1981e). Lee publicly warned the KR that they 'must recognise that the alternative to this is the eventual legitimising of the Vietnamese puppet regime in Kampuchea' (ST, 1980b) - a powerful threat coming from DK's champion at the UN. Singapore pledged to support the non-communist resistance 'in every possible way' but only if they joined the coalition (Japan Times, 1981), denouncing Son Sann when his intransigence stalled negotiations. Thailand threatened to cut off aid to the KPNLF altogether, while cajoling Sihanouk into participating by promising to support his post-war plans for Cambodia (ST, 1981b, 1981e, 1981a; Simon, 1982b: 204; QuinnJudge, 1981; Chanda, 1981). In September, Siddhi embarked on a month-long trip to secure support for the coalition in the West, and in October Singapore brokered a breakthrough agreement to install Sihanouk as President, Son Sann as Prime Minister and the KR's Khieu Samphan as Deputy Prime Minister for Foreign Affairs, with Malaysia pledging aid to give 'beef and teeth' to the coalition when full agreement was reached (FT, 1981; ST, 1981d; 1982). Negotiations on the coalition's operating parameters were subsequently stalled by KR intransigence, so ASEAN once again stoked speculation that DK would lose its UN seat if a coalition was not formed (Sricharatchanya, 1982). Finally on the eve of the factions' meeting in Kuala Lumpur on 22 June 1982, Malaysia offered 'all out economic assistance' in the event of a coalition, on top of the food, clothes and arms already promised (Xinhua, 1982a; ST, 1982). Under this welter of carrots and sticks, the Coalition Government of Democratic Kampuchea (CGDK) was finally formed.

Siddhi's claim that the formation of the coalition was a 'domestic affair and the task of the Kampuchean people' and that 'neither Thailand nor ASEAN has interfered in this affair' is obviously false (Xinhua, 1982b). The key negotiations for the coalition's formation took place in ASEAN capitals, not on Kampuchean soil, amidst intense ASEAN diplomacy, cajoling, threats and promises, without the involvement of the heavily-invoked 'Kampuchean people', with CGDK leaders openly praising ASEAN's coordinating role. Throughout the 1980s, ASEAN diplomacy repeatedly 're-activated' Sihanouk after multiple resignations over KR abuses in order to keep the coalition together (Tasker, 1982; The Nation, 1983; Chanda, 1987).

The construction of the CGDK radically altered the leadership of the government-inexile: to 'dilute' the KR's influence and create a 'nationalist' alternative to the communist regime had been an explicit ASEAN aim (Evans and Rowley, 1984: 2668). Malaysia's Foreign Ministry explained that the goal was to 'beef up' the noncommunist forces, gradually displace the KR and thereby 'increase the chances of the non-communist forces returning to Phnom Penh through a political settlement' (ST, 1981f). ASEAN was now able to exploit the involvement of Sihanouk, a revered founding father of the Non-Aligned Movement, to increase support for its strategy. Explanatory statements indicated his presence was an important factor in increasing the majority in favour of CGDK recognition at the UN in 1982 (Amer, 1990: 54). The 'dilution' of the KR's role also allowed Western states to respond to ASEAN's calls for assistance. This was particularly crucial after the Vietnamese 1984-85 dry season offensive virtually wiped out the CGDK's camps. Washington responded with an 
influx of $\$ 20 \mathrm{~m}$, and annual aid ranged from $\$ 17 \mathrm{~m}$ to $\$ 32 \mathrm{~m}$ thereafter (Mysliwec, 1988: 83; Kiernan, 1993: 199). However, Jakarta rejected Singapore's suggestion of direct ASEAN military aid for the CGDK, threatening to leave ASEAN over the matter (Sricharatchanya, 1981). Notably, Jakarta was unwilling to legitimise ASEAN's behaviour by appealing to a right of counter-intervention, nor to confront Hanoi militarily, even via a proxy, since this would openly compromise ASEAN's 'offended bystander' routine. Nevertheless, with Singapore leading the way, a covert Singaporean-Malaysian-Thai-American group was convened regularly in Bangkok to coordinate assistance to the CGDK. This included arms, ammunition, training, communications equipment, food, and the establishment of a Khmer-language KPNLF radio station with British assistance. The three ASEAN states dispensed just under $\$ 70 \mathrm{~m}$ and were critical in persuading Washington to participate (Lee, 2000: 378-80).

\section{A 'Comprehensive Political Settlement': From ICK to UNTAC}

There is no space here for detailed discussion of the 1991 Paris Peace Agreements (PPA) or the UNTAC operation that deployed the settlement. Here I simply wish to show that, contra Michael Leifer's (1999) argument that ASEAN was consigned to a marginal role during the peace process, with the great powers ultimately dictating policy, ASEAN had already devised many of the headline elements of the PPA in the early 1980s.

The Third Indochina War seemed to confirm ZOPFAN's basic premise, that great power involvement in regional politics was often disastrous for the region. As Indonesia's Foreign Minister stated, 'in principle, the Kampuchean problem is a conflict between Vietnam and the PRC', but Thailand's attempts to mediate between them was quickly rebuffed since the conflict went to the heart of the Sino-Soviet rivalry (Van der Kroef, 1984: 223). ZOPFAN principles were referenced in the 1979 UNGA resolution on the 'Situation in Kampuchea' which warned that 'escalation of the conflict 'increase[d] the danger of further involvement by outside Powers', and from 1980 onwards, ZOPFAN was explicitly referenced, with the UN endorsing ASEAN's model of regional security and calling for all states to implement it (A/RES/34/22; A/RES/35/6; A/35/PV.46: 827; A/35/PV.47: 846; A/RES/35/6).

ZOPFAN's realisation, however, depended on the satisfaction of powerful interests in Cambodia. Suharto and Malaysian Prime Minister Hussein Onn discussed how this might be achieved at Kuantan, Malaysia, in March 1980. The 'Kuantan Declaration' proposed a political settlement that 'specifically recognised Hanoi's security interests in Kampuchea' (Van der Kroef, 1981: 516-7). Cambodia should be made neutral and non-aligned, with a maximum degree of autonomy, but Hanoi would exercise 'effective veto power over much of Cambodia's defence and foreign policy' (Peou, 2000: 140). Van der Kroef (1984) referred to this plan as the 'Finlandization' of Cambodia, an attempt to trade off Cambodian sovereignty to achieve regional stability that clearly contradicts the Westphalian expectations of subaltern realism. Thailand and Singapore rejected the proposal not on the grounds that sacrificing Cambodian sovereignty was wrong in principle but on the grounds that it would 'encourage' rather than restrain Vietnam (Van der Kroef, 1981: 518). 
Nevertheless, the Kuantan principle, that Cambodia must sacrifice some of its sovereignty to achieve regional peace, survived in altered form and was enshrined in the notion of a 'comprehensive political solution', which entered ASEAN and UN vocabularies from 1980 onwards. This necessitated 'guarantees against the introduction of foreign forces' to the country and 'that an independent and sovereign Kampuchea will not be a threat to its neighbours' (A/RES/35/6). ASEAN's campaigning for this option in a context of stalemate led the US, Japan, China, and even Vietnam to soon begin echoing the need for a 'neutral' Cambodia (Van der Kroef, 1984: 224-6) and, by the 1980s, they 'took their cues on the Indochina issue from ASEAN communiqués' (Simon, 1982a). The basic elements of the PPA and the UNTAC operation were identified in these communiqués and ASEAN-sponsored UN resolutions as early as 1980-81 (ASEAN, 1979; 1980; 1981; A/RES/34/22;

A/RES/35/6; A/RES/36/5):

- Total withdrawal of foreign troops, to be verified by the UN;

- Appropriate measures to ensure respect for human rights and the rule of law during the transitional period;

- Respect for Cambodian self-determination, to be realised via democratic elections under UN auspices;

- Repatriation rights for all refugees; and

- The neutralisation of Cambodia, including guarantees against the introduction of foreign forces, respect for Cambodian sovereignty, and guarantees that Cambodia could never become a threat to its neighbours.

These elements were enshrined in the 1981 Declaration of the International Conference on Kampuchea (ICK), for which ASEAN campaigned hard, and this became the basis for all future negotiations (UN, 1981), which included a series of 'Informal Meetings' between the factions in Jakarta in the late 1980s which paved the way for the PPA (Prasad, 2001). Each element is reflected in the final settlement deployed by UNTAC (UN, 1991). Thus, while Leifer correctly noted that ASEAN states were too weak to enforce the settlement themselves and required the Permanent 5 to steer the process to completion, many of the settlement's core aspects were determined by ASEAN's earlier political advocacy. Cambodia was re-born as a semisovereign state, losing control over foreign policy decisions normally reserved for individual states, forced to 'enshrine' its 'perpetual neutrality' in its constitution, forbidden to host foreign bases or form alliances, and subject to renewed intervention if it ever compromised its neutrality in the future.

This is not to argue that ASEAN was satisfied with all aspects of UNTAC. Indeed, they were alarmed by the depth to which the operation penetrated Cambodia's state machinery and society, and ASEAN ambassadors repeatedly complained of UNTAC's ability to 'do things without ASEAN agreeing'. They successfully intervened to pressure Yasushi Akashi, the UN Special Representative in charge of the mission, not to use his extensive powers, which theoretically allowed him to make decisions when the Supreme National Council, the transitional embodiment of Cambodian sovereignty where all factions were represented, was deadlocked (Goulding, 2006).

\section{ASEAN Intervention in Post-War Cambodia}


China's realignment with ASEAN dealt a coup de grace to most of ASEAN's communist insurgencies, and the Soviet Union's post-1986 retrenchment prompted Vietnam to launch doi moi (restructuring) and begin withdrawing from Cambodia: the Cold War in Asia was dying long before the Berlin Wall fell. Stripped of the certainty of ideological struggle, by the early 1990s ASEAN's environment was characterised by uncertainty: Washington's desire to maintain its military presence in East Asia, the intentions of China and India, the continuation of the liberal international trade regime on which ASEAN economies depended - all seemed questionable (Snitwongse, 1995; Weatherbee, 1993). The opportunity provided by the Cold War for 'projection into the planetary game', which was 'a source of internal political cohesion because it allowed the state a central role' (Laïdi, 1998: 19) had also vanished, replaced by the zeitgeist of 'globalisation', leading some to declare 'the end of the nation-state' (Ohmae, 1995). Furthermore, ASEAN states confronted new demands for political participation as a result of economic and social development (Robison and Goodman, 1996). ${ }^{6}$

ASEAN responded to these new uncertainties with a range of initiatives, including the ASEAN Free Trade Area (AFTA), the ASEAN Regional Forum (ARF), and the expansion of ASEAN to cover all Southeast Asia (ASEAN-10). These moves reflected less a desire to achieve concrete goals than to maintain the abstract 'relevance' of ASEAN so as to preserve its function as a diplomatic caucus, a shield for autocratic-developmentalist regimes against threatening global forces. AFTA and ASEAN's membership of APEC was driven by a fear that ASEAN might be superseded by APEC or excluded by the apparent 'bloc-ization' of the global economy which threatened to divert the investment that ASEAN's dirigiste regimes, and social order more broadly, relied upon (Weatherbee, 1993: 415; Chin, 1995: 426; Lim 1996). The ARF's development was driven by the fear that large powers were about to initiate an Asia-Pacific security forum that would marginalize ASEAN or consign it to irrelevance (Acharya, 1995; Buszynski, 1998: 570). Its meetings explicitly focused not on moving towards a concrete telos or resolving specific problems but on enunciating procedural norms (Leifer, 1996) - what Laïdi (1998: 154-6) calls 'regionalism without a goal'. ${ }^{7}$ And ASEAN-10 was justified most often in spite of the frequent physical incapacity of the proposed member-states, Burma, Laos, Cambodia and Vietnam, to participate meaningfully in ASEAN activities (Chin, 1995: 428) ${ }^{8}$ - not by reference to concrete benefits but to the supposed wishes of ASEAN's founders. Hinting at the fundamentally reactive nature of ASEAN's activities, Malaysia's Mahathir Mohamad conceded, 'if we appear to be in a hurry, it is only because ASEAN has little lead time to prepare itself against the growing challenges coming its way' (Mahathir, 1992).

This projection without a project produced a fundamental contradiction. ASEAN was basically unwilling to take responsibility for addressing concrete issues in the region, focusing instead on the procedure of the 'ASEAN Way', masking its inaction with the grand rhetoric of 'community' (Jones and Smith, 2002). But simultaneously, external actors who were themselves unwilling to take direct action were able to exploit ASEAN's claims to manage regional order force ASEAN to intervene. 
Thailand's 'New Look' policy, launched by Chatichai Choonhavan in 1988, aimed, now the threat of communism had evaporated, to 'turn the Indochina battlefield into a trading market', with a 'Greater Thailand' at the centre of a regional economic hub (Um, 1991: 246-8), Bangkok's apparent willingness to recognise the PRK again giving the lie to any 'principled' stand. Although the suddenness of the move took other ASEAN states by surprise (Van der Kroef, 1990: 229), and was resisted by the Thai military, soon this policy of economic predation was replicated across the region. ${ }^{9}$ By the mid-1990s, ASEAN states were Cambodia's major trading partners and, along with Japan, controlled most of its natural resources. Capital-starved Cambodia depended heavily on ASEAN, with Singapore investing $\$ 35 \mathrm{~m}$ and Thailand, $\$ 47 \mathrm{~m}$. Malaysia became Cambodia's largest foreign investor with total investments exceeding \$109m (Moller, 1998: 1095; Peou, 2000: 373-4).

ASEAN had a basic interest in safeguarding these investments by encouraging stability, which looked precarious by the mid-1990s. The 1993 elections produced a fragile coalition between the Cambodian People's Party (CPP) led by former PRK Prime Minister Hun Sen, and the royalist party FUNCINPEC (formerly Moulinaka) led by Prince Ranariddh, son of Prince Sihanouk. Hun and Ranariddh served as Second and First Prime Minister respectively, but the 1993 Electoral Law allowed only one Prime Minister to emerge from the 1998 elections. This, in addition to ingrained patronage systems, the lack of democratic culture, and profound disagreement about how to deal with renewed KR insurgency, ${ }^{10}$ fuelled conflict between these former sworn enemies (Roberts, 2002: 522-8; Findlay, 1995: 110). ASEAN's interventions to maintain calm mainly took the form of threats of withdrawal. Malaysian Foreign Minister Badawi, dispatched to Phnom Penh in May 1996, warned 'against any escalation of violence and said that open hostilities would force ASEAN to leave Cambodia alone'. In December, Mahathir wrote to Hun and Ranariddh, 'urging them to settle their differences and to ensure political stability in the country'. Singapore's Prime Minister Goh made a pointed statement in November, stressing the continued need for stability if investment were to continue. Suharto himself led a large Indonesian delegation to Cambodia in February 1997 to repeat the ASEAN line on stability, while Philippine Foreign Minister Domingo Siazon began to raise doubts about Cambodia's membership of ASEAN (Peou, 2000: 373-5).

Nevertheless, in July 1997 the situation in Cambodia exploded into violence in what is usually referred to as Hun Sen's 'coup' against Ranariddh. ${ }^{11}$ Critical accounts, however, show that Ranariddh had entered into military alliance with the KR and was smuggling arms and soldiers into Phnom Penh to overthrow Hun Sen. Indeed, the government troops that moved against Ranariddh did so on the orders of the bipartite Commission of Eight, established to manage tensions between FUNCINPEC and CPP, while Hun himself was vacationing in Vietnam (FT Asia Intelligence Wire, 1997: 376-8; Kevin, 2000; Peou, 2000). Ranariddh fled to Paris, announcing a coup had taken place before a shot had been fired and calling for international intervention to depose Hun Sen and the renewal of civil war in league with the KR.

FUNCINPEC's war plan seemed to be to seize and hold Pochtenpong airport long enough for a hoped-for UN intervention force to arrive, while linking up with the KR at Anlong Veng (DPA, 1997a; FT, 1997b; Kyodo, 1997b; Kevin, 2000: 602). 
Although some ASEAN states airlifted their nationals from Phnom Penh, ASEAN's initial reaction to these events was to avoid any mention of a 'coup', echoing calls from Japan, Europe and the US for the peaceful resolution of the conflict. ASEAN insisted that Cambodia's entry to ASEAN, which (along with that of Laos and Burma) was due to be signed off later than month, would be unaffected. Indonesian Foreign Minister Ali Alatas stated: 'in principle, the ASEAN commitment to admit the three countries has not changed'. Thailand's Foreign Ministry insisted the events 'would not affect Phnom Penh's scheduled entry into ASEAN... the admission of Cambodia has already been decided' (Xinhua, 1997c; Kyodo, 1997c).

\section{The Bind of Projection: The Imposition of Intervention}

However, Washington, Japan and the EU all insisted ASEAN use its 'leverage' to restore order. The US was particularly insistent, offering 'advice' to ASEAN prior to the emergency ASEAN Ministerial Meeting (AMM) summoned to discuss the crisis and insisting ASEAN 'co-ordinate' its position with Washington. The US swiftly suspended its humanitarian aid (followed by other donors) as a 'clear signal to Hun Sen... that the US will not be conducting business as usual' with him (Kyodo, 1997c; Xinhua, 1997c; The Nation, 1997d; BBC SWB (NHK TV), 1997; Guardian, 1997). The 10 July AMM joint statement (ASEAN, 1997b) illustrated that ASEAN had bowed to this external pressure:

While reaffirming the commitment to the principle of non-interference in the internal affairs of other states, [ASEAN] decided that, in the light of unfortunate circumstances which have resulted from the use of force, the wisest course of action is to delay the admission of Cambodia into ASEAN until a later date... The ASEAN countries stand ready to contribute their efforts to the peaceful resolution of the situation in Cambodia.

The US, apparently unwilling to take direct action itself, was able to exploit ASEAN's 'projection without a project', demanding that ASEAN's claim to manage regional order be substantiated. Coming shortly after a huge furore over Burma's planned accession to the Association, which severely damaged ASEAN-Western relations, and amidst growing dissatisfaction with ASEAN's leadership role in the ARF, ${ }^{12}$ the Cambodian coup put ASEAN's credibility on the line. ASEAN therefore assembled a 'Troika' comprising the Indonesian, Philippine and Thai foreign ministers, which assumed an uncomfortable mediating position, not only between the warring factions, but also between Cambodia and the West. The US established the 'Friends of Cambodia' (FOC) group, comprising the major donor countries, ostensibly to 'support' ASEAN's work, but in reality to supervise it. Washington insisted ASEAN 'coordinate' its position with the US and vowed to 'use its leverage' to ensure Hun Sen was dealt with (Kyodo, 1997a), with Secretary of State Madeleine Albright and her deputy Stanley Roth making frequent visits to and demands of ASEAN states. The fact that the Troika always met a day prior to FOC but did not release its statements until it had consulted with FOC the next day clearly illustrated the power dynamic at work.

The Troika's first mission to Phnom Penh on 19 July generated considerable embarrassment because Hun Sen had already denounced ASEAN's plans to 'interfere in Cambodia's internal affairs', saying, 'let us solve our problems on our own. Please stay out of our internal business'. He publicly rejected their intervention again on the eve of their arrival. Ali Alatas sought to get ASEAN off the hook, stating, 'clearly, of 
this moment, our efforts will stop', but it was not to be so easy (FT, 1997a; NST, 1997; DPA, 1997b; Xinhua, 1997a). Just as the KR and FUNCINPEC were relaunching costly civil war, the IMF suspended its \$120m Structural Adjustment Programme, which comprised 20 per cent of the government's budget, in addition to the 50 per cent constituted by now-suspended foreign aid. Donor withdrawal precipitated a collapse in investor confidence, with GNP growth slumping from 7 per cent in 1996 to zero by 1998. The ARF officially endorsed ASEAN's lead on the issue and Washington piled pressure on Phnom Penh to invite ASEAN back, or lose international aid permanently. Further coercion was applied in September when Washington spearheaded a campaign to seat Ranariddh at the UN instead of Hun Sen's candidate, producing an eventual comprise that left the seat vacant, thus stripping Cambodia once again of its international legitimacy. ${ }^{13}$ Under such circumstances it is unsurprising that the Troika was 'invited' to return, allowing ASEAN to operate coercively beneath the veneer of consent (Kevin, 2000: 595-6; Xinhua, 1997d).

Intervention was thus imposed on both Cambodia and ASEAN, turning ASEAN into the reluctant gatekeeper to Cambodia's international rehabilitation. The following sections briefly summarise the form intervention took, constituting 'creeping conditionality' for ASEAN membership - as soon as one condition was satisfied, another was imposed, largely because intervention not only failed to resolve the fundamental political conflicts that caused the crisis, but in fact exacerbated them.

\section{From 'Caretaker Government' to 'Free and Fair Elections'}

Despite Badawi's promise that ASEAN would not act as the 'international police' by dictating to Cambodia and 'would not put forward any proposal... because it may be misconstrued as interfering' (Xinhua, 1997b), the Troika did in fact put forward a 'caretaker government' proposal on its first visit to Phnom Penh. The suggestion that Hun Sen and Ranariddh both select deputies to run the government until elections scheduled for May 1998 were held was, as mentioned above, publicly denounced (Moller, 1998: 1097; Peou, 2000: 387).

Taking its cue from Washington - Albright stated that FOC's role was 'to support the ASEAN initiative and to work to achieve free and fair elections in 1998' (UPI, 1997) - ASEAN therefore shifted tack at its special AMM on 11 August, calling for 'free and fair elections' involving 'all political parties', and offering technical assistance. Ranarridh had by then been replaced as FUNCINPEC leader by Ung Huot following a vote on 6 August, but ASEAN refused to accept this on the grounds that 'ASEAN member states recognise states, not governments' (ASEAN, 1997a), a claim clearly falsified by ASEAN's earlier policies on Cambodia. However, Thailand's refusal now to support the renewed insurgency, and the AMM's emphasis on 'holding elections in 1998 that outsiders will not be able to criticise', illustrates well what was directly at stake: international credibility, rather than domestic social order (Peou, 2000: 389; BBC SWB (National Voice of Cambodia), 1997).

ASEAN thus focused on encouraging the self-exiled politicians of FUNCINPEC and the opposition Sam Rainsy Party (SRP) to return home, mobilising UN resources to safeguard their return, and putting forward ceasefire proposals to end civil conflict. The sticking point was Hun Sen's insistence on trying Ranariddh for his crimes 
(Antara, 1997b, 1997a). ASEAN's efforts were, however, cut short by the Asian financial crisis, which, full-blown by October 1997, had devastating social, economic and political effects across the sub-region. The initiative largely passed from the Troika to Thailand, and Japan, which coordinated its efforts with ASEAN (The Nation, 1997a). In talks in Tokyo in November, Hun Sen agreed to a range of proposals, including pardoning Ranariddh to facilitate his participation in elections, a ceasefire, and guarantees for the safety of returning self-exiles (Peou, 2000: 397-8). Thailand stepped into the void left by the Troika by successfully pushing for the postponement of elections, visiting the factions and pressing for a ceasefire, and offering direct mediation in Bangkok (Mainchi Daily News, 1997; The Nation, 1997b, 1997c; DPA, 1998a; Kyodo, 1998d). Hun Sen's attempts to end the intervention in Cambodia by suggesting that ASEAN countries 'should solve their own economic crises first', and repeatedly hinting that he might withdraw Cambodia's application to join ASEAN, were insufficient to rescue either side from the bind they found themselves in (Kyodo, 1998c; DPA, 1997c). There was simply too much at stake for Cambodia, facing a plunge back into civil war with insufficient resources to fight off the KR, to block ASEAN's interference. Ranariddh was eventually coerced into returning to Cambodia when the EU, and then ASEAN, exploiting the room for manoeuvre this created (Washington opposed it), dropped their insistence on his personal participation as a condition for the recognition of election results (DPA, 1998h, 1998g). After a ceasefire, trial date and pardon arrangements had been implemented, ASEAN states agreed to send eight election monitors each and to mobilise international financial support for the July 1998 elections (Xinhua, 1998d; DPA, 1998f).

\section{From Elections to Coalition Formation}

Alatas indicated there would be 'no difficulties' for Cambodia in gaining ASEAN membership after its elections (AFP, 1998b), a sentiment echoed by the other ASEAN foreign ministers (Asia Pulse, 1997; Xinhua, 1998b). Yet after the elections, a new condition was imposed: the formation of a coalition government. ASEAN's interventions had merely forced Cambodia's warring parties to participate in elections; they had not resolved the fundamental political conflict underlying the events of July 1997. The CPP gained 41.4 per cent of the vote, FUNCINPEC 31.7 per cent and SRP 14.3 per cent. While CPP was thus the biggest party, it lacked the parliamentary majority necessary to form a government and invited both opposition parties to form a coalition (DPA, 1998e). Rather than agreeing to negotiate, they exploited the international attention focused on Cambodia by rejecting the election results - certified by international observers as 'free and fair' (DPA, 1998d; FT, 1998) - holding demonstrations calling for armed international intervention to overthrow Hun Sen, and leaving the country to render the National Assembly inquorate and induce political paralysis (BBC SWB (Radio Australia), 1998; DPA, 1998c; Christian Science Monitor, 1998; Phnom Penh Post, 1998b; 1998a). Rather than creating political peace and stability, ASEAN's interventions had facilitated this paralysis by allowing Ranariddh a new lease of political life, despite his plotting with the KR to overthrow the democratically-elected government, and granting FUNCINPEC and SRP enhanced bargaining power. ASEAN's new condition - the formation of a coalition - both reflected the failure of intervention to bring stability to Cambodia, and exacerbated these problems. 
In a statement on 9 September, ASEAN called for 'all parties' to 'resolve their differences in the spirit of national reconciliation... through dialogue and consultation... so that Cambodia would soon form a new government that fulfils the aspirations of the Cambodian people and the desire of the countries in the region' (Xinhua, 1998a, emphasis added). Given that ASEAN states were themselves succumbing to international intervention in the form of predatory IMF 'rescue' packages (see Feldstein, 1998; Robison et al., 2000; Thakur, 2000), ASEAN relied on Thailand's Sukhumbhand Paribatra to carry out intensive shuttle diplomacy between the parties, pushing them to enter into negotiations, backed by Japan, the EU and the US. Paribatra was eventually able to manoeuvre the factions into negotiations under Sihanouk, with a coalition agreement finally being announced three months after the elections. The extra leverage afforded by external intervention allowed Ranariddh to hold out for half the ministerial posts and the position of President of the National Assembly for himself (The Nation, 1998; Xinhua, 1998c; BP, 1998). A deal was also struck to create a Senate, to be chaired by a CPP official.

\section{From Coalition Formation to Senate Establishment}

Badawi claimed that 'no more issues' would block Cambodian membership after the formation of a government (Bernama, 1998), but as soon as the coalition deal was announced, ASEAN changed its conditions again in a further reflection of its unwillingness to take responsibility for Cambodia. After the AMM on 14 November, the Thai Foreign Ministry indicated that membership would now be conditional upon the constitutional amendment required to create the Senate (Kyodo, 1998b). The new condition was explained by reference to continued fears for Cambodia's stability, with the Philippines noting there could be more 'fighting among them. We will have to resolve it again. Others are saying "didn't we get burned there already?" (AFP, 1998a). As the Straits Times noted, Cambodia's entry could expose ASEAN to 'recrimination' if the situation came 'unstuck', which would 'damage ASEAN's credibility', especially in the wake of the financial crisis. The newspaper, often taken to express official sentiment in Singapore, suggested Cambodia needed the 'discipline and restraint imposed by probation', which should be extended for another year, with targets to 'put the government's integrity to the test', including the formation of a Senate, military reform and the handling of international aid (ST, 1998b).

The Singaporean government had aroused Indonesia's wrath by insisting during the financial crisis that Jakarta should abide by the strictures of the Structural Adjustment Programme imposed upon it (Henderson, 1999: 62). With these strictures 'striking at the heart' of Indonesia's social, economic and political power relations (Robison and Rosser, 2001: 179), it is perhaps unsurprising that Indonesia struck out at continued conditionality for Cambodia. Alatas asked, 'since when should ASEAN sit in judgement about how governments work and make it a condition for entry? Did we do that when Vietnam entered, or Laos, or Myanmar, or before that Brunei Darussalam? We never said, "Well, I hope your government works and we will just see first..." I mean, this an additional conditionality $[$ sic $]$ that moves towards internal interference' (DPA, 1998b). Malaysia, Brunei, Laos and Vietnam felt similarly, and the re-seating of Cambodia at the UN in December reduced ASEAN's leverage substantially. Singapore's Goh Chok Tong continued to insist on conditionality (ST, 1998a), publicly refuted by Alatas (Kyodo, 1998a). ${ }^{14}$ The bizarre face-saving compromise produced at ASEAN's Hanoi summit in December reflected ASEAN's deep disunity, 
with Cambodia being admitted to ASEAN but its formal admission ceremony being delayed until the Senate was formed (ASEAN, 1998; Severino 2006: 64). This resulted in ASEAN's intervention outlasting that of the international donors, who began to negotiate new aid packages in February. That month, Paribatra embarked on yet another mission to Phnom Penh to push for swift progress on the Senate (Kyodo, 1999), and with the constitutional amendment finally in place, Cambodia was formally admitted to ASEAN in April 1999, completing its international rehabilitation and ending ASEAN's intervention in that country. ${ }^{15}$

\section{Conclusion}

ASEAN intervened in Cambodian affairs repeatedly over the twenty-year period considered by this article, undermining the claims of subaltern realism and constructivists that third-world states are passionately attached to an abstract principle of sovereignty. ASEAN's emphasis on non-intervention was ultimately a political rather than a normative principle, expressing a defence of weak, capitalist regimes from subversion by separatist or communist movements being sponsored by outside powers. Vietnam's invasion of Cambodia threatened not simply an abstract principle of sovereignty (which ASEAN was not prepared to defend) but the political principle of the survival of ASEAN's non-communist regimes. The intervention that followed illustrated ASEAN elites' determination to defend the economic and political status quo. A similar argument could explain ASEAN's defence of Indonesia's annexation of East Timor in 1975.

ASEAN's interests in re-intervening in Cambodia in the post-Cold War era are much less clear. A basic interest in regional 'stability' and the safeguarding of investments in Cambodia do not seem sufficient to explain the institution of conditionality for membership in the Association for the first and last time in the group's history. Compared to ASEAN's earlier interventions - vociferous diplomatic campaigning, the formation of counter-regimes and the arming and supporting of guerrilla movements - 'creeping conditionality' was a rather tame approach, resisted by some of its members, that reflected ASEAN's diminished interests. It was ASEAN's claim to manage regional order that allowed external actors to compel it to intervene in the conflict, or risk this claim being discredited, with possible attendant consequences for the autonomy of ASEAN's regimes in the face of global pressures. ASEAN has similarly been urged in recent years to push Burma towards democracy, and again it has had little choice but to comply, however ineffectually and reluctantly. ASEAN has been very reluctant to take on responsibility for problems arising within its new states; but the West's own refusal to take on these problems directly themselves, preferring to use ASEAN to do its 'dirty work', suggests a similar reluctance to exercise power in the absence of obvious interests. 


\section{Acknowledgements}

For helpful comments on earlier versions of this paper I am grateful to Andrew Hurrell, Alastair Fraser, Christopher Bickerton, the participants of the Sovereignty and its Discontents workshop on Southern Responses to the New Interventionism (Oxford, November 2006), and two anonymous reviewers.

\section{References}

Acharya, A. (1995) 'ASEAN and Asia-Pacific Multilateralism: Managing Regional Security', in Acharya, A. \& Stubbs, R. (eds.) New Challenges for ASEAN: Emerging Policy Issues, Vancouver: University of British Columbia Press. (2000) The Quest for Identity: International Relations of Southeast Asia, Oxford: Oxford University Press. (2001) Constructing a Security Community in Southeast Asia: ASEAN and the Problem of Regional Order, London: Routledge.

Agence France Presse (AFP) (1998a), 21 November.

------- (1998b), 16 March.

Alagappa, M. (1993) 'Regionalism and the Quest for Security: ASEAN and the Cambodian Conflict', Journal of International Affairs, 46:2, 439-467.

-------- (1995) 'The Bases of Legitimacy', in Alagappa, M. (ed.) Political Legitimacy in Southeast Asia: The Quest for Moral Authority, Stanford: Stanford University Press.

Alexander, R. J. (1999) International Maoism in the Developing World London: Praeger.

Amer, R. (1990) 'The United Nations and Kampuchea: The Issue of Representation and its Implications', Bulletin of Concerned Asian Scholars, 22:3, 52-60. (1992) The United Nations and Foreign Military Interventions: A Comparative Study of the Application of the Charter, Dept of Peace and Conflict Research, Uppsala University: Uppsala, Sweden.

-------- (1996) 'The United Nations and the Cambodian Famine and Refugee Crisis', in Amer, R., Saravanamuttu, J. \& Wallensteen, P. (eds.) The Cambodian Conflict, 1979-1991: From Intervention to Resolution, Dept of Peace and Conflict Research, Uppsala University: Uppsala, Sweden

Anderson, B. R. (1998) The Spectre of Comparisons: Nationalism, Southeast Asia and the World, London: Verso.

Antara (1997a), 23 October. - (1997b), 3 October.

Antolik, M. (1990) ASEAN and the Diplomacy of Accommodation, London: M. E. Sharpe.

ASEAN (1967) ASEAN Declaration. Bangkok. (1971) ZOPFAN Declaration. Kuala Lumpur. (1976) Treaty of Amity and Cooperation. Jakarta. (1979) Joint Communiqué of the 12th ASEAN Ministerial Meeting. Bali. (1980) Joint Communiqué of the 13th ASEAN Ministerial Meeting. Kuala Lumpur.

- (1981) Joint Communiqué of the 14th ASEAN Ministerial Meeting. Manila. (1997a) Joint Press Statement: Special ASEAN Foreign Ministers Meeting. Singapore. 
(1997b) Joint Statement of the Special Meeting of the ASEAN Foreign

Ministers on Cambodia. Kuala Lumpur.

(1998) Hanoi Declaration. Hanoi.

Asia Pulse (1997), 26 July.

Ayoob, M. (1995) The Third World Security Predicament: State Making, Regional

Conflict, and the International System, London: Lynne Rienner.

BBC SWB (National Voice of Cambodia) (1997), 4 August.

BBC SWB (NHK TV) (1997), 9 July.

BBC SWB (Radio Australia) (1998), 1 August.

Bernama (1998), 15 November.

Bangkok Post (BP) (1979), 1 February.

------- (1998), 16 October.

Buszynski, L. (1994) 'Thailand's Foreign Policy: Management of a Regional Vision', Asian Survey, 34:8, 721-737.

(1998) 'ASEAN's New Challenges', Pacific Affairs, 70:4, 555-577.

Chanda, N. (1981) 'The Road to Singapore', Far Eastern Economic Review, 11

September, 9-10.

-------- (1987) 'The Prince Makes Waves', Far Eastern Economic Review, 18 June, 48 .

Chin, K. W. (1995) 'ASEAN: Consolidation and Institutional Change', Pacific

Review, 8:3, 424-439.

Christian Science Monitor (1998).

Daily Telegraph (1979a), 17 April. (1979b), 11 January.

Dibb, P. (2001) 'Indonesia: The Key to South-East Asia's Security', International Affairs, 77:4, 829-842.

Dosch, J. (2006) The Changing Dynamics of Southeast Asian Politics, Boulder: Lynne Rienner.

Doyle, M. W. \& Suntharalingam, N. (1994) 'The UN in Cambodia: Lessons for Complex Peacekeeping', International Peacekeeping, 1:2, 117-147.

Deutsche Presse Agentur (DPA) (1997a), 10 July.

(1997b), 18 July.

- (1997c), 9 December.

(1998a), 22 January.

(1998b), 11 December.

(1998c), 7 October.

(1998d), 26 July.

(1998e), 30 July.

(1998f), 23 March.

(1998g), 5 March.

(1998h), 16 January.

Evans, G. \& Rowley, K. (1984) Red Brotherhood at War: Indochina Since the Fall of Saigon, London: Verso.

Feldstein, M. (1998) 'Refocusing the IMF', Foreign Affairs, 79:2, 20-33.

Findlay, T. (1995) Cambodia: The Legacy and Lessons of UNTAC, Oxford: Oxford University Press.

Frost, F. (1991) 'The Cambodia Conflict: The Path Towards Peace', Contemporary Southeast Asia, 13:2, 119-163.

Financial Times (FT) (1981), 5 December. (1997a), 11 July. 
(1997b), 8 July.

(1998), 28 July.

FT Asia Intelligence Wire (1997), 7 July.

Girling, J. L. S. (1981) Thailand: Society and Politics, Ithaca: Cornell University Press.

Goulding, M. (2006) Interview with the author. Oxford, 25 January.

Guardian (1979), 15 January.

------- (1997), 12 July.

Heinberger, J. E. (1994) Peacekeeping in Transition: The United Nations in Cambodia, New York: Twentieth Century Fund Press.

Henderson, J. (1999) Reassessing ASEAN, Oxford: Oxford University Press.

Hernandez, C. (1998) 'Towards Re-Examining the Non-Intervention Principle in ASEAN Political Cooperation', Indonesian Quarterly, 26:3, 164-170.

Hughes, C. (forthcoming) 'Transnational Networks and Democratic Contestation in Cambodia', Democratization.

International Herald Tribune (IHT) (1979), 30 July.

Japan Times (1981), 15 September.

Jennar, R. M. (1994) 'UNTAC: “International Triumph” in Cambodia?' Security Dialogue, 25:2, 145-156.

Johnston, A. I. (2003) 'Socialization in International Institutions: The ASEAN Way and International Relations Theory', in Ikenberry, G. J. \& Mastanduno, M. (eds.) International Relations Theory and the Asia-Pacific, New York: Columbia University Press.

Jones, D. M. \& Smith, M. L. R. (2002) 'ASEAN's Imitation Community', Orbis, 46:1, 93-109.

Kao, K. K. \& Kaplan, J. A. (Eds.) (2000) ASEAN's Non-Interference Policy: Principles Under Pressure?, London: ASEAN Academic Press.

Kessler, R. J. (1989) Rebellion and Repression in the Philippines New Haven: Yale University Press.

Kevin, T. (2000) 'Cambodia's International Rehabilitation, 1997-2000', Contemporary Southeast Asia, 22:3, 594-612.

Khong, Y. F. (1997) 'ASEAN and the Southeast Asian Security Complex', in Lake, D. A. \& Morgan, P. M. (eds.) Regional Orders: Building Security in a New World, University Park, PA: Pennsylvania State University Press.

Kiernan, B. (1993) 'The Inclusion of the Khmer Rouge in the Cambodian Peace Process: Causes and Consequences', in Kiernan, B. (ed.) Genocide and Democracy in Cambodia: The Khmer Rouge, the United Nations and the International Community, New Haven: Yale University Southeast Asia Studies. (2002) 'Introduction: Conflict in Cambodia, 1945-2002', Critical Asian Studies, 34:4, 483-95.

Kyodo (1997a), 24 July. (1997b), 11 July. (1997c), 6 July. (1998a), 16 December. (1998b), 14 November. (1998c), 12 January. (1998d), 29 January. (1999), 17 February. 
Laïdi, Z. (1998) A World Without Meaning: The Crisis of Meaning in International Politics, London: Routledge.

Lee, K. Y. (2000) From Third World to First - The Singapore Story: 1965-2000, Singapore: Singapore Press Holdings.

Leifer, M. (1996) The ASEAN Regional Forum: Extending ASEAN's Model of Regional Security, Oxford: Oxford University Press/ Institute for Strategic Studies.

(1999) 'The ASEAN Peace Process: A Category Mistake', Pacific Review, $12: 1,25-38$.

Lim, L. Y. C. (1996) 'ASEAN: New Modes of Economic Cooperation', in Wurfel, D. \& Burton, B. (eds.) Southeast Asian in the New World Order: The Political Economy of a Dynamic Region, Macmillan: London.

Mahathir, M. (1992) ASEAN - The Next Generation: Old Wisdoms and New Directions. Speech to First ASEAN Congress, Hotel Istana, Kuala Lumpur.

Mainchi Daily News (1997), 8 November.

Moller, K. (1998) 'Cambodia and Burma: The ASEAN Way Ends Here', Asian Survey, 38:12, 1087-1104.

Mysliwec, E. (1988) Punishing the Poor: The International Isolation of Kampuchea, Oxford: Oxfam.

New Straits Times (NST) (1997), 18 July.

New York Times (NYT) (1979a), 24 April. (1979b), 1 June.

Observer (1979), 1 July.

Ohmae, K. (1995) The End of the Nation-State: The Rise of Regional Economies, London: HarperCollins.

Paribatra, S. (1984) 'Strategic Implications of the Indochina Conflict: Thai Perspectives', Asian Affairs, 11:3, 28-46.

Peou, S. (2000) Intervention and Change in Cambodia: Towards Democracy?, Singapore: ISEAS.

Phnom Penh Post (1998a), 2 October. (1998b), 18 September.

Prasad, M. N. (2001) Indonesia's Role in the Resolution of the Cambodian Problem, Aldershot, UK: Ashgate.

Quinn-Judge, P. (1981) 'An Arranged Marriage', Far Eastern Economic Review, 11 September, 8-9.

Ramcharan, R. (2000) 'ASEAN and Non-Interference: A Principle Maintained', Pacific Review, 22:1, 60-84.

Richardson, M. (1982) 'ASEAN and Indochinese Refugees', in Broinowski, A. (ed.) Understanding ASEAN, London: Macmillan.

Roberts, D. (2002) 'Democratization, Elite Transition, and Violence in Cambodia, 1991-1999’, Critical Asian Studies, 34:4, 520-538.

Robison, R., Beeson, M., Jayasuriya, K. \& Kim, H.-R. (Eds.) (2000) Politics and Markets in the Wake of the Asian Crisis, London: Routledge.

Robison, R. \& Goodman, D. S. G. (Eds.) (1996) The New Rich in Asia: Mobile Phones, McDonald's and Middle-Class Revolution, London: Routledge.

Robison, R. \& Rosser, A. (2001) 'Surviving the Meltdown: Liberal Reform and Political Oligarchy in Indonesia', in Robison, R., Beeson, M., Jayasuriya, K. \& Kim, H.-R. (eds.) Politics and Markets in the Wake of the Asian Crisis, London: Routledge. 
Rosenberg, J. (1994) The Empire of Civil Society: A Critique of the Realist Theory of International Relations, London: Verso.

Saravanamuttu, J. (1996) 'The ASEAN Perspective and Role in the Cambodian Peace Process', in Amer, R., Saravanamuttu, J. \& Wallensteen, P. (eds.) The Cambodian Conflict, 1979-1991: From Intervention to Resolution, Dept of Peace and Conflict Research, Uppsala University: Uppsala, Sweden.

Severino, R. C. (2006) Southeast Asia in Search of an ASEAN Community: Insights from the Former ASEAN Secretary-General, ISEAS: Singapore.

Shawcross, W. (1984) The Quality of Mercy: Cambodia, Holocaust, and Modern Conscience, New York: Simon and Schuster.

Shui, Y. (2002) 'An Account of Chinese Diplomats Accompanying the Government of Democratic Kampuchea's move to the Cardamom Mountains (translated by Paul Marks)', Critical Asian Studies, 34:4, 497-519.

Silverman, J. M. (1975) 'The Domino Theory: Alternatives to a Self-Fulfilling Prophecy', Asian Survey, 15:11, 915-939.

Simon, S. W. (1982a) The ASEAN States and Regional Security, Stanford: Hoover Institution Press.

(1982b) 'Cambodia and Regional Diplomacy', Southeast Asian Affairs 1982, Singapore: ISEAS.

Smith, M. (1991) Burma: Insurgency and the Politics of Ethnicity, London: Zed Books.

Snitwongse, K. (1995) 'ASEAN's Security Cooperation: Searching for a Regional Order', Pacific Review, 8:3, 518-530.

Sricharatchanya, P. (1981) 'Paper Over the Cracks', Far Eastern Economic Review, 18 December, 8-9.

(1982) 'Persistent Matchmakers', Far Eastern Economic Review, 23 April, 40-41.

Straits Times (ST) (1979a), 2 February. (1979b), 27 April.

(1979c), 25 May.

(1979d), 9 July.

(1980a), 15 November.

(1980b), 26 September.

(1981a), 7 November.

(1981b), 5 February.

(1981c), 19 April.

(1981d), 22 September.

(1981e), 28 May.

(1981f), 23 October.

(1982), 11 June.

(1998a), 16 December.

(1998b), 11 December.

Sucharithanarugse, W. (2000) 'The Concept of "Human Security" Extended:

"Asianizing” the Paradigm', in Tow, W. T., Thakur, R. C. \& Hyun, I.-T. (eds.)

Asia's Emerging Regional Order: Reconciling Traditional and Human

Security, Tokyo: UN University Press.

Tang, J. T. H. (Ed.) (1995) Human Rights and International Relations in the Asia-

Pacific, New York: Pinter.

Tasker, R. (1982) 'Trumped-Up Trio', Far Eastern Economic Review, 25 June, 8-10. 
Terry, F. (2002) Condemned to Repeat? The Paradox of Humanitarian Action, Ithaca: Cornell University Press.

Tesón, F. R. (1997) Humanitarian Intervention: An Inquiry into Law and Morality, New York: Transnational Publishers.

Thakur, R. C. (2000) 'Human Security Regimes', in Tow, W. T., Thakur, R. C. \& Hyun, I.-T. (eds.) Asia's Emerging Regional Order: Reconciling Traditional and Human Security, Tokyo: UN University Press.

The Nation (1983), 4 January.

------- (1997a), 10 November. (1997b), 20 November. (1997c), 31 December. (1997d), 11 July.

(1998), 12 September.

Um, K. (1989) 'Cambodia in 1989: Still Talking But No Settlement', Asian Survey, 30:1, 96-104.

(1991) 'Thailand and the Dynamics of Economic and Security Complex in Mainland Southeast Asia', Contemporary Southeast Asia, 13:3, 245-270.

UN (1981) Report of the International Conference on Kampuchea: New York, 13-17 July 1981, New York: United Nations.

(1991) Agreements On A Comprehensive Political Settlement Of The Cambodia Conflict, Annex 3. Paris.

United Press International (UPI) (1997), 28 July.

Van der Kroef, J. M. (1980) 'The Cambodian Conflict in Southeast Asia's Strategic Considerations', Asian Profile, 8:2, 181-196.

(1981) 'ASEAN, Hanoi and the Kampuchean Conflict: Between "Kuantan" and a "Third Alternative", Asian Survey, 21:5, 515-535.

(1983) 'Refugees and Rebels: Dimensions of the Thai-Kampuchean Border Conflict', Asian Affairs, 10:1, 19-36.

(1984) 'Kampuchea: The Road to Finlandization, 1983', Asian Profile, 13:3, 221-241.

(1990) 'Thailand and Cambodia: Between "Trading Market" and Civil War', Asian Profile, 18:3, 227-38.

Vickery, M. (1987) 'Refugee Politics: The Khmer Camp System in Thailand', in Ablin, D. A. \& Hood, M. (eds.) The Cambodian Agony, London, M. E. Sharpe.

Weatherbee, D. E. (1993) 'Southeast Asia's New Agenda', Current History, 92:578, 413-420.

Wheeler, N. J. (2000) Saving Strangers: Humanitarian Intervention in International Society, Oxford: Oxford University Press.

Xinhua (1982a), 22 June.

(1982b), 14 June.

(1997a), 19 July.

(1997b), 11 July.

(1997c), 7 July.

(1997d), 21 July.

(1998a), 9 September.

(1998b), 24 July.

(1998c), 16 September.

(1998d), 3 April.

Yomiuri Shinbun (1979), 9 July 1979. 
${ }^{1}$ Such remarks were entirely typical (Dibb, 2001: 834; Hernandez, 1998; Kao and Kaplan, 2000; Ramcharan, 2000; Sucharithanarugse, 2000: 60).

${ }^{2}$ The first was supposedly the explicit support lent to Corazon Aquino's government in the Philippines in 1986 and the attendant call for a peaceful political solution to the ongoing socio-political crisis there. ${ }^{3}$ As is relatively common in studies of ASEAN, and particularly given the politically sensitive nature of this topic, the lack of secondary material on some parts of the period, it has been necessary at times to rely on newspaper accounts to reconstruct a narrative in the absence of access to government archives. Wherever possible, triangulation was used to help confirm accounts and multiple sources are often cited. As with any such research, the narrative and conclusions are subject to the subsequent revelation of any more authoritative official documents.

${ }^{4}$ There is no space here to fully rehearse the history behind these events. Briefly, the US intervention in and bombing of Cambodia emiserated and radicalised the population, pushing them into the arms of the KR, a left-wing guerrilla group opposing the US-backed Lon Nol dictatorship. The KR swept to power in 1975 with Vietnamese and Chinese assistance, renaming the Kingdom of Cambodia 'Democratic Kampuchea' (DK; 'Kampuchea' being closer to the phonetic sound of the country in Khmer - the two names are used interchangeably in this article as they were during the period). But almost immediately after cementing his dominance, Pol Pot, in league with China (which Vietnam had turned against for Beijing's excessive interference) began attacking Vietnam and persecuting ethnic Vietnamese citizens as part of a genocidal campaign claiming $1.7 \mathrm{~m}$ lives. Vietnam was forced into an alliance with Moscow and invaded Cambodia alongside a rebel KR faction that had previously staged an unsuccessful revolt against Pol Pot before fleeing to Vietnam. Hanoi had previously defended the KR regime in international forums, unsuccessfully seeking a modus vivendi with Pol Pot. Its motives in invading were not so much humanitarian (though it clearly had positive results for the Cambodian people), as self-interested - the goal being to remove a dangerous regime that menaced Vietnam's borders constantly with significant loss of life and food security.

${ }^{5}$ These notations indicate UN documents. A indicates the General Assembly, 34 indicates the 34th session (1979), PV indicates provisional verbatim record, and the final number indicates the meeting number, followed by the page number.

${ }^{6}$ It is important to note, as Robison and Goodman et al. (1996) do, that the growth of urban middle classes in the region did not automatically produce demands for liberal democracy, as mainstream theorists of democratisation expected. Often the middle classes were in fact highly bound up in the illiberal power structures that had helped create them via massive state intervention. Nevertheless, these changes generally produced rising demand for political participation in some way, as well as protests against corruption and inefficiencies that hampered middle-class business interests.

${ }^{7}$ Some constructivists argue that the goal is in fact to 'socialise' China. Johnston (2003) provides the most convincing argument along these lines, but only succeeds in showing that a small office of bureaucrats has been effectively 'socialised'. In any case such arguments are post-hoc rationalisations of the ARF and ASEAN's incapacity to actually use the ARF to solve any concrete problems, ignoring the proximate causes of ARF's establishment.

${ }^{8}$ By the mid-1990s there were over 220 meetings per year under ASEAN auspices. This presents a heavy diplomatic load for any developing country, particularly those targeted for ASEAN membership, which had few officials capable of speaking English (the international language of the region), and sometimes could not afford the initial membership contribution of $\$ 1 \mathrm{~m}$ (and then $\$ 750,000$ per anum thereafter). Cambodia did not even have embassies in the majority of ASEAN countries by 1997.

${ }^{9}$ The military benefited hugely from the black market trade made possible only by continued conflict and the embargo of legitimate cross-border trade. China was also alarmed by the shift and publicly denounced it for fear that it was a prelude to cutting assistance to its KR client and excluding it from the ongoing peace process. Beijing welcomed the 1991 Thai military coup against Chatichai as 'correct and just', and coup leader General Suchinda called Pol Pot a 'nice guy' (Kiernan, 1993: 218; 2002: 488). However, social change in Thailand, including the rise of the middle class and the demise of communism as a threat that could legitimise military rule, meant the military regime was beaten back and democracy restored by 1993. Although the Thai military continued to assist the KR until at least 1995, with serious consequences for the peace process (Buszynski, 1994: 731; Doyle and Suntharalingam, 1994: 144-5; Findlay, 1995: 4, 94, 166-7; Frost, 1991: 130; Heinberger, 1994: 2; Jennar, 1994: 150), its dominance had been broken and the politics of economic predation superseded the 'red scare'.

${ }^{10}$ The KR had refused to canton and disarm as required by the Paris Agreements, while the Cambodian government and the remaining resistance factions had. When the KR boycotted the 1993 elections and resumed their hostilities, they were thus able to make massive gains, controlling or imperilling up to 
half of the country by 1994 . The renewed civil war cost the Cambodian government $\$ 185 \mathrm{~m}$, a third of its national budget, which was clearly unsustainable (Kevin, 2000: 600, n. 9; Peou, 2000: 240). While Hun Sen favoured selective amnesties, conditional upon the cessation of military and political activities, to encourage defections from the KR (a scheme that proved most controversial with the West but which had actually achieved its goal by the end of the 1990s), by May 1997 Ranariddh was suggesting bringing the KR directly back into Cambodian national politics. See:

http://www.geocities.com/khmerchronology/1995.htm.

${ }^{11}$ This was the account favoured by Western media at the time and much academic writing since (e.g., Moller, 1998: 1097; Peou, 2000: 298).

${ }^{12}$ For instance, to China's delight, ASEAN refused to allow the ARF to discuss directly the emerging territorial conflicts in the South China Sea in 1995. US Assistant Secretary of State Winston Lord said this called into question whether the ARF was a 'credible organisation'. Japan was also looking for a forum to actually make progress on North-East Asian security issues, while the US even suggested transforming APEC into a defence forum because it was so dissatisfied with the ARF (Buszynski, 1998: 572-5).

${ }^{13}$ ASEAN claimed to oppose the move, but apparently dared not vote against it, since the UNGA endorsed the compromise without a vote (A/52/PV.76).

${ }^{14}$ Singapore's views remained particularly important since it held the chair of the ASEAN Standing Committee, tasked with organising ASEAN's business, which in this case included the organisation of the official membership ceremony for Cambodia.

${ }^{15}$ However, Cambodia's long-term emiseration, to which ASEAN's interventions clearly contributed by helping prolong armed conflict, has transformed the country into the 'playground' of international NGOs who seek to dictate government policy and manage democratic contestation (Dosch, 2006: 141 60 ; Hughes, forthcoming). 